\title{
REVITALISASI PENDIDIKAN \\ BERBASIS KEUNGGULAN LOKAL DALAM \\ BINGKAI KTSP
}

\author{
Anung Priambodo \\ Dosen Fakultas IImu Keolahragaan Universitas Negeri Surabaya
}

\begin{abstract}
Indonesia's biodiversity and all the other potentials that are fairly abundant must be utilized to improve the welfare of the people. One mechanism that is expected to be able to transform potential into aktus is education. Through the Ministry of National Education, the government sought the implementation level of the education curriculum $(\mathrm{SBC})$ to connect the implementation of local excellence as part of the curriculum in schools. Local advantages can be put in the subjects of local content (Muatan lokal) or integrated with other subjects. It is expected that learners can identify and develop potential advantages in the area to be objects that benefit for society.

Keywords : revitalization, local advantages, and KTSP.
\end{abstract}

\section{Pendahuluan}

Sumber daya manusia (SDM) merupakan aset yang paling dibutuhkan untuk mencapai kemajuan suatu bangsa. Adanya sumber daya manusia yang berkualitas, maka hambatan seperti kurangnya dukungan sumber daya alam bukan sesuatu yang tidak bisa dipecahkan oleh SDM yang sehat, kreatif, dan inovatif. Mengacu data Indeks Pembangunan Manusia (Human Development Index/HDI) tahun 2010, Indonesia menempati peringkat 108. Jauh berada dibawah negara-negara ASEAN, seperti Singapura (27), Brunei Darusalam (37), Malaysia (57) dan Pilipina (97), dan hanya lebih tinggi dari Vietnam (113) dan India (119). IPM ini ditetapkan berdasarkan tiga kriteria utama yaitu angka harapan hidup (kesehatan), melek huruf (tingkat pendidikan), dan pendapatan perkapita.

Sebagai salah satu kriteria utama pembangunan sumber daya manusia, maka pendidikan memegang peran yang sangat penting. Indonesia adalah negara yang sangat kaya sumber daya alam, namun demikian bangsa Indonesia belum mampu mengoptimalkan potensi yang ada 
untuk meningkatkan sumber daya manusia. Dengan pendidikan yang berkualitas, diharapkan manusia memiliki pengertian untuk menjaga pola hidup sehat sehingga tingkat kesehatan masyarakat meningkat. Jika kesehatan meningkat, maka diharapkan manusia mampu aktif bekerja dan kreatif sehingga pendapatan perkapita juga meningkat. Dengan demikian pendidikan memegang peranan yang sangat penting dalam meningkatkan dua aspek yang lain dalam indeks pembangunan manusia.

Jika menilik pada keunggulan yang dimiliki oleh bangsa-bangsa lain, maka Indonesia seharusnya juga merupakan suatu bangsa yang memiliki keunggulan, baik pada keunggulan komparatif maupun keunggulan kompetitif. Keunggulan komparatif terkait dengan sumber daya alam yang tersediam, sedangkan keunggulan kompetitif terkait dengan kemampuan sumber daya manusianya (SDM). Dalam hal keunggulan komparatif, bangsa Indonesia memiliki alam yang kaya dan iklim yang bersahabat. Bahkan, dengan meminjam lagu dari Koes Plus "Bukan Lautan, Hanya Kolam Susu" tongkat pun bisa hidup ditanam di Indonesia. Tetapi, perlu disadari bahwa keunggulan ini justru membuat bangsa ini lalai sehingga, tidak melakukan apa-apa (karya besar) dalam waktu yang lama. Sementara untuk keunggulan kompetitif, berupa potensi yang dapat dikembangkan, juga tertinggal dengan negara lain. Jepang adalah negara yang memiliki area (keunggulan komparatif) sangat terbatas, tetapi luar biasa baik dalam keunggulan kompetitif.

Di ASEAN, bangsa ini juga harus mengakui keunggulan daya saing Singapura, Malaysia, maupun Thailand. Singapura menjadi yang terbaik di Asia Tenggara dan berada pada posisi 6 dunia. Malaysia pada peringkat 24, sedangkan Thailand 36. Pembentukan daya saing, terutama keunggulan kompetitif dapat dilakukan dengan pendidikan. Kurikulum yang dikembangkan oleh suatu lembaga pendidikan akan menentukan output pendidikan yang memiliki daya saing suatu bangsa. Sehubungan dengan hal itu, maka diperlukan model kurikulum yang dapat menumbuhkan daya saing bangsa. Sejak digulirkan Juni 2006, banyak persoalan muncul terkait implementasi Kurikulum 'Tingkat satuan Pendidikan (K'TSP) di sekolah mulai dari tidak memadainya kualitas SDM untuk menjabarkan K'TSP di satuan pendidikan, kurangnya sarana prasarana, guru tidak memahami secara utuh KTSP baik dari segi konsep maupun implementasi di lapangan. 
Seyogyanya, KTSP ditetapkan dengan tujuan mendekatkan hasilhasil pendidikan di sekolah dengan kebutuhan yang ada. Kebijakan pelaksanaan KTSP didasarkan pada kebijakan desentralisasi pendidikan. Jikalau hal ini dapat diwujudkan, tentunya tidak ada lagi pengangguran yang tidak memiliki keterampilan memadai untuk mengelola potensi yang ada di daerahnya. Dalam panduan K'TSP juga dinyatakan beberapa istilah yang menunjukkan perbedaan pelaksanaan KTSP dengan kurikulum sebelumnya. Istilah yang dimaksud adalah adanya muatan lokal dan kegiatan pengembangan diri disamping mata pelajaran wajib. K'TSP juga mengakomodasi pendidikan berbasis keunggulan lokal (PBKL). Melalui pendidikan berbasis keunggulan lokal, maka sekolah bisa ikut berperan dalam mempersiapkan SDM yang memiliki kesiapan untuk mengelola potensi daerah.

\section{Pendidikan Berbasis Keunggulan Lokal}

Sejak adanya reformasi tahun 1998, terjadi perubahan yang sangat mendasar terhadap semua aspek kehidupan bangsa Indonesia termasuk pada bidang pendidikan, yaitu dari semula bersifat sentralistik menjadi desentralistik. Melalui desentralisasi pendidikan diharapkan permasalahan pokok pendidikan, yaitu masalah mutu, pemerataan, relevansi, efisiensi dan manajemen dapat terpecahkan. Desentralisasi pendidikan merupakan suatu upaya mencari paradigma baru untuk menemukan falsafah dan sistem pendidikan nasional. Dasar penyelenggaraan desentralisasi pendidikan adalah dikeluarkannya aturan-aturan baru seiring dengan gerakan reformasi di Indonesia. Aturan-aturan tersebut adalah :

- Undang-Undang No. 22 Tahun 1999: Pemerintah Daerah menuntut pelaksanaan otonomi dan wawasan demokrasi dalam penyelenggaraan pendidikan.

- Undang-Undang RI No. 20 Tahun 2003 Bab XIV Pasal 50 Ayat 5: Pemerintah Kabupaten/Kota mengelola pendidikan dasar dan menengah, serta satuan pendidikan yang berbasis pendidikan lokal.

- Undang-Undang RI No. 20 Th. 2003 Bab X Pasal 36 ayat 2: Kurikulum pada semua jenjang dan jenis pendidikan dikembangkan dengan prinsip diversifikasi sesuai dengan satuan pendidikan, potensi daerah dan peserta didik. 
- PP RI No. 19 Tahun 2005 Bab III Pasal 14 Ayat 1: Kurikulum untuk SMP/MTS/SMPLB dan SMA/MA atau bentuk lain yang sederajat dapat memasukkan pendidikan berbasis keunggulan lokal.

Berdasarkan peraturan perundang-undangan di atas sudah diatur bahwa pelaksanaan pendidikan diluar kewenangan pemerintah pusat dan harus dilakukan di daerah. Oleh karena itu, pengembangan kurikulum sebagai salah satu substansi utama dalam pengembangan pendidikan perlu didesentralisasikan, terutama kebutuhan siswa, keadaan sekolah, dan kondisi daerah. Sehubungan dengan kondisi daerah dan potensi daerah di Indonesia yang cukup beragam, maka perlu daerah meningkatkan potensi daerah melalui pendidikan di sekolah.

Desentralisasi pendidikan memungkinkan daerah dapat mengembangkan potensi wilayahnya sesuai dengan situasi dan kondisi lokal. Salah satu kebijakan yang dapat dikembangkan pendidikan adalah melalui pendidikan yang berbasis keunggulan lokal. Pendidikan berbasis keunggulan lokal dan global adalah pendidikan yang memanfaatkan keunggulan lokal dan global dalam aspek ekonomi, seni budaya, SDM, bahasa, teknologi informasi dan komunikasi, ekologi, dan lain-lain ke dalam kurikulum sekolah.

Diharapkan keunggulan yang dimiliki suatu daerah dapat lebih memberdayakan penduduknya, sehingga mampu meningkatkan pendapatan atau meningkatkan PAD (Pendapatan Asli Daerah). Karena manfaat dan pendapatan yang diperoleh menjadikan penduduk daerah tersebut berupaya untuk melindungi, melestarikan, dan meningkatkan kualitas keunggulan lokal yang dimiliki daerahnya agar bermanfaat bagi penduduk daerah tersebut serta mendorong persaingan secara kompetitif pada tingkat nasional maupun global. Satuan pendidikan yang berbasis keunggulan lokal merupakan paradigma baru pendidikan untuk mendorong percepatan pembangunan di daerah berdasarkan potensi yang dimiliki oleh masyarakat lokal.

\section{Pengembangan K'TSP}

K'TSP dikembangkan sesuai dengan relevansinya oleh setiap kelompok atau satuan pendidikan dibawah koordinasi dan supervisi dinas pendidikan atau kantor Departemen Agama Kabupaten/Kota untuk pendidikan 
dasar dan provinsi untuk pendidikan menengah. Pengembangan KTSP mengacu pada SI dan SKL dan berpedoman pada panduan penyusunan kurikulum yang disusun oleh BSNP, serta memperhatikan pertimbangan komite sekolah/madrasah. Penyusunan KTSP untuk pendidikan khusus dikoordinasi dan disupervisi oleh dinas pendidikan propinsi dan berpedoman pada SI dan SKL serta panduan penyusunan kurikulum yang disusun oleh BSNP.

KTSP dikembangkan berdasarkan prinsip-prinsip sebagai berikut:

- Berpusat pada potensi, perkembangan, kebutuhan, dan kepentingan peserta didik dan lingkungannya. Peserta didik memiliki posisi sentral untuk mengembangkan kompetensinya agar menjadi manusia yang beriman dan bertakwa kepada Tuhan Yang Maha Esa, berakhlak mulia, sehat, berilmu, cakap, kreatif, mandiri dan menjadi warga negara yang demokratis serta bertanggung jawab.

- Beragam dan terpadu. Kurikulum dikembangkan dengan memperhatikan keragaman karakteristik peserta didik, kondisi daerah, jenjang dan jenis pendidikan, serta menghargai, dan tidak diskriminatif terhadap perbedaan agama, suku, budaya, adat istiadat, status sosial ekonomi, dan jender. Kurikulum meliputi substansi komponen muatan wajib kurikulum, muatan lokal, dan pengembangan diri secara terpadu.

- Tanggap terhadap perkembangan ilmu pengetahuan, teknologi, dan seni. Kurikulum dikembangkan atas dasar kesadaran bahwa ilmu pengetahuan, teknologi dan seni yang berkembang secara dinamis. Oleh karena itu, semangat dan isi kurikulum memberikan pengalaman belajar peserta didik untuk mengikuti dan memanfaatkan perkembangan ilmu pengetahuan, teknologi, dan seni.

- Relevan dengan kebutuhan kehidupan. Pengembangan kurikulum dilakukan dengan melibatkan pemangku kepentingan (stakebolders) untuk menjamin relevansi pendidikan dengan kebutuhan kehidupan, termasuk di dalamnya kehidupan kemasyarakatan, dunia usaha, dan kerja.

- Menyeluruh dan berkesinambungan. Substansi kurikulum mencakup keseluruhan dimensi kompetensi, bidang kajian keilmuan 


\section{Anung Priambodo}

dan mata pelajaran yang direncanakan dan disajikan secara berkesinambungan antar semua jenjang pendidikan.

- Belajar sepanjang hayat. Kurikulum diarahkan kepada proses pengembangan, pembudayaan, dan pemberdayaan peserta didik yang berlangsung sepanjang hayat.

- Seimbang antara kepentingan nasional dan kepentingan daerah. Kurikulum dikembangkan dengan memperhatikan kepentingan nasional dan kepentingan daerah untuk membangun kehidupan bermasyarakat, berbangsa, dan bernegara.

\section{Prinsip Penetapan Muatan Lokal dalam K'TSP}

Salah satu tujuan diberlakukannya KTSP adalah meningkatkan relevansi pendidikan dengan kebutuhan hidup nyata yang ada di masyarakat. Untuk mewujudkan hal tersebut, maka pelaksanaan K'TSP juga mengakomodasi kurikulum yang bertujuan untuk mengembangkan potensi atau keunggulan daerah masing-masing satuan pendidikan. Dalam KTSP kurikulum tersebut ditetapkan berupa muatan lokal.

Latar belakang adanya pengembangan muatan lokal antara lain: (1) otonomi daerah, (2) desentralisasi, (3) multikultural, (4) pendidikan di sekolah perlu memberikan wawasan yang luas pada peserta didik tentang kekhususan yang ada di lingkungannya, dan (5) Kurikulum harus dikembangkan dengan memperhatikan karakteristik sosial budaya masyarakat setempat dan menunjang kelestariaannya. Materi muatan lokal bertujuan untuk memberikan bekal pengetahuan, keterampilan dan perilaku kepada peserta didik agar mereka memiliki wawasan yang mantap tentang keadaan lingkungan dan kebutuhan masyarakat sesuai dengan nilai-nilai/aturan yang berlaku di daerahnya dan mendukung kelangsungan pembangunan daerah serta pembangunan nasional. Secara terperinci tujuan mulok agar peserta didik dapat:

- Mengenal dan menjadi lebih akrab dengan lingkungan alam, sosial, dan budayanya,

- Memiliki bekal kemampuan dan keterampilan serta pengetahuan mengenai daerahnya yang berguna bagi dirinya maupun lingkungan masyarakat pada umumnya, 
- Memiliki sikap dan perilaku yang selaras dengan nilai-nilai/aturanaturan yang berlaku di daerahnya, serta melestarikan dan mengembangkan nilai-nilai luhur budaya setempat dalam rangka menunjang pembangunan nasional.

Penetapan materi muatan lokal ditentukan oleh beberapa pihak diantaranya tim pengembang kurikulum sekolah, tim pengembang kurikulum propinsi/kabupaten/ kota, LPMP, LPT'K/perguruan tinggi, instansi, atau lembaga diluar dinas pendidikan seperti pemerintah daerah, dunia industri serta tokoh masyarakat.

Penyusunan muatan lokal ditetapkan dengan mengacu pada prinsipprinsip sebagai berikut:

- Materi pembelajaran disesuaikan dengan tingkat perkembangan peserta didik, baik yang berkaitan dengan pengetahuan, cara berpikir, emosional, dan sosial,

- Pelaksanaan Mulok tidak mengganggu pelaksanaan komponen mata pelajaran (komponen A dalam struktur kurikulum),

- Kegiatan pembelajaran diatur agar tidak memberatkan peserta didik, oleh karena itu dalam pelaksanaan Mulok diharapkan tidak ada pekerjaan rumah (PR),

- Program pembelajaran dikembangkan dengan melihat kedekatan secara fisik dan secara psikis,

- Bahan pembelajaran disusun berdasarkan prinsip (a) bertitik tolak dari hal-hal konkret ke abstrak; (b) dikembangkan dari yang diketahui ke yang belum diketahui; (c) dari pengalaman lama ke pengalaman baru; (d) dari yang mudah/sederhana ke yang lebih sukar/rumit,

- Bahan pembelajaran bermakna bagi peserta didik dan dapat membantu peserta didik dalam kehidupan sehari-hari,

- Kompetensi dan materi pembelajaran hendaknya memberikan keluwesan bagi pendidik dalam memilih metode mengajar dan sumber belajar,

- Pendidik hendaknya dapat memilih dan menggunakan strategi yang melibatkan peserta didik aktif dalam proses pembelajaran baik secara mental, fisik, maupun sosial, 
- Materi pembelajaran muatan lokal harus bersifat utuh dalam arti mengacu kepada suatu tujuan pembelajaran yang jelas dan memberi makna kepada peserta didik,

- Muatan Lokal tertentu tidak harus secara terus-menerus diajarkan mulai dari kelas awal sampai akhir tiap satuan pendidikan. Muatan Lokal dapat disusun dan diajarkan hanya dalam jangka waktu satu semester atau dua semester/satu tahun pembelajaran.

\section{Keterkaitan KTSP dengan Pendidikan Berbasis Keunggulan Lokal}

Mengacu pada uraian pada bab II, maka seharusnya implementasi kurikulum berbasis keunggulan lokal telah terakomodasi dalam KTSP. Perdebatan isi kurikulum dalam pendidikan selalu menjadi permasalahan yang penting selama bertahun-tahun. Menurut Fagerlind dan Saha (1989) ada dua pandangan umum dalam menyusun kurikulum. Yang pertama yaitu pandangan tradisional yang memandang proses pendidikan formal sebagai upaya untuk mengajarkan nilai-nilai dan norma dalam masyarakat untuk mencapai individu yang dewasa. Perspektif yang kedua menekankan pada belajar untuk menguasai materi yang berguna dalam kehidupan praktis seperti matematika, fisika dan kimia serta berbagai subyek vokasional seperti mengetik, mengerjakan kayu, industri dan sebagainya.

Dengan adanya desentralisasi pendidikan, seharusnya pendidikan berbasis keunggulan lokal bisa diupayakan sesuai dengan tujuan KTSP. Dalam Peraturan Pemerintah Nomor 19 Tahun 2005 tentang Standar Nasional Pendidikan bab III Standar Isi pasal 14 ayat (2) menyatakan bahwa pendidikan berbasis keunggulan lokal dapat merupakan bagian dari pendidikan kelompok mata pelajaran agama dan akhlak mulia, pendidikan kelompok matapelajaran kewarganegaraan dan kepribadian, pendidikan kelompok mata pelajaran ilmu pengetahuan dan teknologi, pendidikan kelompok mata pelajaran estetika atau kelompok mata pelajaran pendidikan jasmani, olahraga dan kesehatan; dan ayat (3) Pendidikan berbasis keunggulan lokal dapat diperoleh peserta didik dari satuan pendidikan yang bersangkutan atau dari satuan pendidikan nonformal yang sudah memperoleh akreditasi. 
Selanjutnya dalam pasal 17 ayat (1) menyatakan bahwa (KTSP) dikembangkan sesuai dengan satuan pendidikan, potensi/karakteristik daerah, sosial budaya masyarakat setempat dan peserta didik. Berdasarkan PP tersebut, seharusnya K'TSP sudah mampu mengakomodasi aspirasi pendidikan berbasis keunggulan lokal, namun pelaksanaan KTSP selama ini belum banyak memberikan perubahan yang nyata dalam pembentukan kecakapan hidup (life skills) yang sesuai dengan kebutuhan daerah. Untuk mewujudkan keberhasilan kurikulum pendidikan berbasis keunggulan lokal, sebaiknya kurikulum pendidikan merupakan ramuan antara kurikulum nasional dan nilai-nilai daerah, antara lain nilai-nilai budaya, sumber daya alam, potensi, serta pemikiran yang layak dilestarikan melalui jalur pendidikan formal.

Sekolah-sekolah yang berbasis potensi daerah akan mendapat dukungan masyarakat karena lulusannya dapat bekerja langsung di daerah masingmasing. Paradigma ini mengandung arti bahwa pendidikan kejuruan dan vokasi mempunyai peran penting dalam pengembangan sekolah berbasis keunggulan lokal. Untuk itu, dalam pengembangan sekolah berbasis keunggulan lokal perlu melakukan kajian dengan melibatkan semua stakebolder pendidikan untuk merumuskan bersama tentang keunggulan lokal, sehingga keunggulan lokal ini terintegrasi dalam materi pembelajaran yang disusun sesuai jenjang pendidikan.

Dalam pelaksanaan KTSP, seyogyanya sekolah menetapkan visi misi yang mengandung muatan untuk mengembangkan potensi daerah.Sebagai contoh pada sekolah menengah yang tinggal di lingkungan pusat wisata budaya seperti di Bali harus memasukkan visi dan misi sekolahnya sebagai sekolah yang berwawasan wisata budaya. Demikian pula pada sekolah di lingkungan ekonomi kerajinan seperti Jepara Jawa Tengah, atau kerajinan wayang kulit di Kecamatan Manyaran, Kabupaten Wonogiri harus memasukkan secara tegas dalam visi misi sekolahnya bahwa sekolah tersebut berbasis seni kerajinan unggul di daerahnya tersebut. Sementara itu pada sekolah-sekolah yang memiliki keunggulan alam yang dapat dikembangkan untuk melahirkan daya saing tingkat global memasukkan visi-misi yang terkait dengan pengembangan sumber alam tersebut. Sekolah Menengah di NTB yang tinggal di dekat pantai dapat memasukkan visi 


\section{Anung Priambodo}

misi sekolahnya secara eksplisit bahwa sekolah tersebut mengembangkan sumber daya air seperti kerang mutiara, dan seterusnya.

Visi dan misi yang dicantumkan dalam KTSP di sekolah-sekolah tersebut bukan sekedar merupakan slogan. Visi misi haruslah sebuah semboyan umum yang masuk akal dan dapat diimplementasikan dalam kegiatan pembelajaran dengan dukungan lingkungan yang memadai. Perumusan visi misi harus didasarkan pada studi kelayakan yang memadai dan pemikiran futurologis yang dapat mengangkat citra sekolah itu sebagai sekolah yang bercitra khusus dengan keunggulan tertentu yang membedakan dengan sekolah-sekolah lain. Keunggulan kurikulum yang dikembangkan akan menghasilkan output lulusan yang dalam jangka panjang dapat bersaing pada tingkat yang lebih luas, yakni nasional dan global.

Pengembangan kurikulum berbasis keunggulan lokal tidak dimaksudkan untuk mengembangkan mata pelajaran tersendiri. Akan tetapi dapat diintegrasikan dengan mata pelajaran atau bidang studi lain yang relevan dengan keunggulan lokal yang hendak dikembangkan oleh suatu sekolah. Mata pelajaran atau bidang studi yang menjadi sasaran integrasi materi keunggulan lokal yang hendak dikembangkan dalam KTSP tiap sekolah tidak sama. Hal itu tergantung dari pilihan keunggulan yang hendak dikembangkan dari suatu sekolah.

Pembelajaran materi pelajaran keunggulan lokal dapat ditempuh dengan tiga cara, yaitu mandiri, kolaborasi, dan integrasi. Yang dimaksud dengan penyelenggaraan secara mandiri yaitu sekolah secara sepenuhnya memberikan materi keunggulan lokal di dalam sekolah termasuk dalam proses belajar mengajar, guru pembelajar, dan saranaprasarana pendukungnya. Pembelajaran secara kolaborasi dimaksudkan bahwa sekolah menjalin kerjasama dengan instansi terkait untuk mengimplementasikan kurikulum berbasis keunggulan lokal, misalnya dengan dinas pariwisata, dinas perindustrian, lembaga kerajinan, galery seni, paguyuban dalang, dan sebagainya. Penyelenggaraannya di sekolah, tetapi dengan mendatangkan pengajar dari lembaga mitra yang kompeten. Cara ketiga hampir sama dengan cara kedua, tetapi penyelenggaraannya di luar sekolah tetapi di tempat lembaga mitra tersebut. Untuk menjamin keberlanjutan pelaksanaan program pendidikan berbasis keunggulan lokal, maka program pembelajarannya harus menjadi bagian integral 
dari keseluruhan proses pembelajaran yang diselenggarakan oleh satuan pendidikan yang bersangkutan.

\section{Implementasi PBKL di Indonesia}

Filosofi pendidikan berbasis keunggulan lokal (PKLB) sebenarnya bisa diaplikasikan sejak diterapkannya Kurikulum Tingkat Satuan Pendidikan (KTSP). Namun pelaksanaan KTSP tidak menunjukkan dampak perubahan yang berarti. Hal ini terjadi, karena kurangnya keleluasaan yang diberikan oleh pemerintah kepada sekolah untuk memasukkan keunggulan lokal baik alam, budaya, adat istiadat, dan sebagainya. Penekanan tolak ukur keberhasilan sekolah dari hasil ujian nasional masih cukup mendominasi arah pendidikan. Adanya dua perspektif tujuan yang berbeda ini menyebabkan pelaksanaan KTSP di sekolah terkesan setengah hati.

DalamK'TSPjugasudah ditetapkantujuan dan prinsip-prinsippenetapan muatan lokal sebagai media untuk mendekatkan hasil pendidikan dengan kebutuhan daerah. Namun demikian, fakta di lapangan menunjukkan tidak adanya keleluasaan dalam menentukan muatan lokal satuan pendidikan. Muatan lokal seharusnya ditetapkan oleh seluruh stakeholderyang ada dalam satuan pendidikan, yaitu tim pengembang kurikulum yang ada di sekolah, LPMP, LPTK, dunia industri/usaha, dan masyarakat. Kenyataannya, muatan lokal yang ada di sekolah-sekolah di Jawa Timur misalnya hampir seluruhnya "seragam", misalnya bahasa daerah, menjahit atau memasak. $\mathrm{Hal}$ tersebut tentunya belum sesuai dengan kebutuhan dan karakteristik sekolah. Contoh salah satu sekolah swasta yang didominasi etnis Tionghoa harus menguasai bahasa daerah Jawa.

Sekolah-sekolah kejuruan di Indonesia juga sudah cukup banyak, yaitu melalui sekolah menengah kejuruan (SMK) bidang mesin, listrik, akuntansi, dan sebagainya. Ada beberapa pendidikan program diploma untuk menyiapkan mahasiswa dalam menguasai suatu keterampilan tertentu. Hal tersebut sangat baik dan mendukung tujuan pendidikan keterampilan, namun seringkali keberadaan sekolah-sekolah ini tidak didasarkan pada kondisi dan potensi daerah yang ada, namun lebih kepada "trend berdasarkan kebutuhan global, misalnya keterampilan komputer, akuntansi, mesin, dan sebagainya. Tidak spesifik daerah/lokal tersebut, 
misalnya pendidikan khusus teknologi pangan jagung, buah-buahan, kerajinan bambu, perikanan ait tawar, dan sebagainya.

Selama ini penentuan muatan lokal dan pendidikan vokasional seperti SMK masih ditetapkan sesuai petunjuk dari pemegang otoritas yang tertinggi, belum sepenuhnya mengakomodasi kebutuhan masyarakat. Indonesia cenderung "latah" dalam menyelenggarakan pendidikan tergantung pada bidang yang saat ini "trendy" dan mampu mendatangkan keuntungan finansial. Seandainya muncul SMK dengan bidang kekhususan yang unik, misalnya teknologi pertanian atau kerajinan akan perlu persiapan kurikulum dan sarana prasarana yang sangat kompleks. Namun bukan berarti hal tersebut tidak mungkin diwujudkan. Sumber informasi menyatakan bahwa salah satu keberhasilan Propinsi Gorontalo menjadi propinsi agropolitan adalah dimasukkannya bidang pertanian dalam kurikulum sekolah. (http://ilmusdm.wordpress.com/2008/05/15/fadelmuhammad-dari-propinsi-agropolitan-menuju-propinsi-inovasi, tgl akses 3 April 2011).

Seharusnya penentuan muatan lokal dan pembukaan SMK dengan bidang kekhususan yang sesuai dengan kebutuhan daerah tidak akan menimbulkan banyak pertentangan, jika dilakukan dengan menggandeng universitas yang menyelenggarakan program studi yang relevan. Hal ini sangat sesuai dengan prinsip community college yang ada di Amerika. Jadi sebelum memasuki universitas, lulusan SMA/SMK sudah memiliki keterampilan yang bisa digunakan untuk mengelola keunggulan lokal, namun juga bisa mempermudah untuk melanjutkan kuliah pada bidang yang sesuai. Selanjutnya universitas yang bersangkutan juga menjalin mitra dengan dunia industri. Dengan demikian, SDM yang masuk di perusahaan sudah memiliki pengetahuan dan keterampilan yang memadai.

Konsep yang telah diuraikan tersebut cukup ideal, namun pelaksanaan pendidikan berbasis keunggulan lokal juga makin sulit diwujudkan tanpa adanya kebijakan yang tepat dari pemegang otoritas pendidikan terkait pengembangan potensi daerah melalui pendidikan dan sistem penilaian. Untuk itu perlu keberanian bagi pemegang otoritas pendidikan untuk mengubah perspektif pendidikan nasional kepada pendidikan yang berbasis keunggulan lokal. Adanya berbagai kepentingan pribadi dan 
golongan seringkali mewarnai arah pendidikan, sehingga pendidikan tidak lagi direncanakan berdasarkan kondisi dan potensi yang sesungguhnya.

\section{Penutup}

Tujuan diberlakukannya KTSP adalah untuk mendekatkan relevansi hasil pendidikan dengan kebutuhan masyarakat. KTSP sangat berpihak pada diintegrasikannya kurikulum yang mengakomodasi keunggulan lokal baik pada aspek sumber daya alam, budaya, seni, bahasa dan sebagainya. Selain mata pelajaran wajib, KTSP mensyaratkan adanya muatan lokal dan kegiatan pengembangan diri. Muatan lokal seyogyanya ditetapkan oleh seluruh stakebolder yang ada dalam satuan pendidikan dengan mengutamakan keunggulan lokal.

Pelaksanaan mata pelajaran muatan lokal tidak boleh mengganggu mata pelajaran wajib sehingga seharusnya muatan lokal tidak selalu cenderung "seragam" pada tiap satuan pendidikan, tetapi benar-benar memiliki kekhususan sesuai keunggulan daerah. Sekolah Menengah Kejuruan (SMK) merupakan media yang sangat tepat untuk mengembangkan pendidikan berbasis keunggulan lokal. Sayangnya, SMK yang ada di Indonesia juga cenderung "seragam", tidak memiliki kekhususan yang sesuai keunggulan lokal. SMK yang ada yaitu pada bidang mesin, listrik, komputer, akuntansi, dan tata boga/tata busana. PBKL akan terlaksana dengan baik, jika ada upaya membangun pendidikan yang berkelanjutan. Sekolah harus diberikan keleluasaan untuk melaksanakan K'TSP dan memilih muatan lokal yang benar-benar bisa memberikan kecakapan hidup (life skills) kepada siswanya sesuai keunggulan lokal.

\section{DAF'TAR PUS'TAKA}

Coombs, P.H. (1968). The World Educational Crisis. A System Analysis.

New York. Oxford University Press. London Toronto.

Depdiknas (2009). Buku Saku Kurikulum Tingkat Satuan Pendidikan (KTSP) Sekolah Menengah Pertama.Jakarta, Dirjen Mandikdasmen. Fagerlind I \& Saha L.J (1989). Education \& National Development. A Comparative Perspective. 2nd Edition. Pergamond Press. http://17862pascasarjanaunigal.blogspot.com/2008/07/program- 
implementasi-pbkl.html, tanggal akses 8-4-2011.

http://dedidwitagama.wordpress.com/2008/05/23/model-kurikulumberbasis-keunggulan-lokal-prof-dr-wasino/, tanggal akses 29 Maret 2011.

http://bataviase.co.id/node/295126, Masalah Pengangguran dan Kondisi Ketenagakerjaan di Indonesia, tanggal akses 12-4-2011.

http://www.gudangmateri.com/2010/10/pengembangan-bahan-ajarmuatan-lokal.html, tanggal akses 20-4-2011.

http://psikologi-online.com/kegagalan-sistem-pendidikan-asia, tanggal akses 15-4-2011.

http://en.wikipedia.org/wiki/Community_college, tanggal akses 20-42011.

Peraturan Pemerintah Nomer 19 tahun 2005 tentang Standar Nasional Pendidikan.

The Jakarta Post, Jakarta | Fri, 11/05/2010 9:54 AM | Headlines "RI Ranks 108 in HDI, Norway best place to live: UN.

The Jakarta Post, Jakarta | Mon, 04/29/2002 7:02 AM | National "RI must invest in human development .

Undang-Undang Republik Indonesia Nomor 20 Tahun 2003. Sistem Pendidikan Nasional. Bandung. Citra Umbara.

Wijaya, I.S (2011). Studi Komparatif Pendidikan Di Kawasan Asia: RRC, Korea Selatan Dan Jepang. Educare: Jurnal Pendidikan dan Budaya. http://educare.e-fkipunla.net. 